\title{
THE DETERMINANTS OF THE READINESS TO LET GO AMONG SENIOR GENERATION OWNER-MANAGERS OF SMALL AND MEDIUM-SIZED FAMILY BUSINESSES
}

\author{
Stephan van der Merwe \\ Potchefstroom Business School, North-West University \\ Accepted April 2010
}

\begin{abstract}
The objective of this study was to assess the determinants of the readiness of the senior generation owner-managers to finally transfer the management and control of the family business to the younger generation. Data from 504 questionnaires linked to 81 family businesses were collected and analysed. An Oblimin oblique rotation was carried out on the principal components of the exploratory factor analysis. Five factors with eigen-values greater than one, explaining 62.64 per cent of the variance, were extracted. These five factors describing the theoretical dimensions of the dependent variable were: the senior generation owner-manager's readiness to let go, and the independent variables of retirement planning, perceived suitability of the successor, estate planning, and the perceived liquidity of the business after the transfer. No significant practical differences relating to these five factors could be found between the perceptions of male and female respondents, the senior and younger generation family members or family members involved in medium-sized or small businesses. Practical recommendations are suggested to ensure a smooth final transfer of the management and control of the business to the younger generation family members.
\end{abstract}

JEL D13, 21

\section{1 Introduction}

The important contribution of family businesses to economic growth and wealth creation in the world has been emphasised by numerous scholars (inter alia, Basu, 2004: 13; Morck \& Yeung, 2004: 391; Astrachan \& Shanker, 2003: 212). Van der Merwe (1998: 3) points out that family businesses have been making a positive contribution to the South African economy for the past 300 years. Ackerman (2001: 325) concurs that approximately 80 per cent of businesses in South Africa could be classified as family businesses and that they comprise 60 per cent of the companies listed on the Johannesburg Stock Exchange.

Although family businesses play a vital role in the world economy, this sector has received little attention, partly because of the difficulty in obtaining reliable data on these firms (Villalonga \& Amit, 2006: 414). However, various scholars highlight the fact that family business research has more recently been included in mainstream business research (Steier \& Ward, 2006; Klein, Astrachan \& Smyrnios, 2005: 321; Chrisman, Chua \& Steier, 2003; Bird, Welsh, Astrachan $\&$ Pistrui, 2002).

Brockhaus (1996: 3) points out that relatively little research on family-run businesses has been carried out in South Africa. During the past decade, such research gained more momentum (Eybers, 2010; Farrington, 2009; Venter, Farrington \& Boshoff, 2009; Adendorff, 2004; Venter, 2003a; Venter, 2003b; Van der Merwe, 1998), but more scientifically-based research is urgently needed. Against this barren backdrop of scientific value-added research, there is ample justification for pursuing more earnest investigation into the unique challenges 
facing family businesses globally, both generally and specifically in the South African business environment.

Various scholars have discussed the role of the senior generation of owner-managers in relation to succession in family businesses and their emotional struggle in passing ownership and control to the successor (Brown \& Coverly, 1999; Goldberg, 1996). The willingness of the senior generation owner-manager to hand over the business is of critical importance in ensuring a smooth succession (Venter, Boshoff \& Maas, 2003: 3; Sharma, Chua \& Chrisman, 2000: 236; Matthews, Moore \& Fialko, 1999: 163).

For the purposes of this study, the definition of Ibrahim and Ellis (2004: 5) has been adopted. They defined a family business as follows: at least 51 per cent of the business is owned by a single family; moreover, at least two family members are involved in the management or operational activities in the business; and the transfer of leadership to younger generation family members is anticipated. The South African National Small Business Act (1996) and the National Small Business Amendment Act (29/2004: 2) classify micro, very small, small and medium-sized businesses as businesses that employ fewer than 200 full-time paid employees.

For two reasons, therefore, this study will target small and medium-sized family businesses in South Africa: firstly, the role of the small business sector in creating jobs and distributing wealth is becoming increasingly important; and, secondly, most family businesses are found in this sector.

\section{2}

\section{Problem statement}

As family businesses are a primary contributor to economic development and job creation in the world, their general lack of longevity is cause for concern. The successful transfer of the business to the younger generation family members is important for a healthy and sustainable family business. The younger generation could contribute significantly to the survival of the family business by injecting new energy and vitality. The senior generation owner-managers are, however, often emotionally attached to the business and it is hard for them to relinquish control. The successful transfer of the business from the senior to the younger generation of family members is an important step in ensuring its sustainability.

Adequate attention should be given to the necessary planning for the transition, thereby honouring the established process. In this way, the inherent fragility of family businesses could be transformed into enhanced robustness and health, which would be advantageous to both the family and its business.

This study aims to expand on the limited information that exists regarding ownership succession in family businesses by investigating the factors that impact on the senior generation owner-manager's readiness to transfer the business to the younger generation family members.

\section{3}

\section{Objectives of the study}

Senior generation owner-managers should understand the dynamics of the succession process, which would help them cope with the emotions associated with transferring the business to the younger generation. Against this background, the primary objective of this study is twofold: first to identify the determinants that could affect the readiness of the senior generation owner-manager to let go of the business and transfer it to the younger generation family members; second, to make practical recommendations on actions that families could take to effect a smooth final transfer of the management and control of the business to the younger generation family members, thereby ensuring the sustainability of the family business for future generations.

In order to address the primary objective of this study, the following secondary objectives have been formulated:

- To undertake a theoretical investigation into the determinants of the readiness of the senior generation owner-manager to transfer the business to the younger generation family members; 
- To determine the items that could measure those determinants;

- To determine the validity and reliability of the measuring instrument;

- To investigate the relationships between the dependent variable, readiness of the senior generation owner-manager to let go, and the independent variables identified during the theoretical investigation;

- To investigate the relationship between the variables and selected demographic variables; and

- To put forward recommendations based on the empirical results of this study in order to assist family businesses in ensuring a smooth transfer of the business to the younger generation family members.

\section{4}

\section{Operationalisation of variables}

'Letting go' means relinquishing control and leadership of a family business and is one of the most emotionally difficult experiences in a senior generation owner-manager's life. Few family business owners readily embrace the idea of not being in the position of leadership any more, with its attendant feeling that one is doing something meaningful and powerful, along with the accompanying prestige in the community and respect from family members (Aronoff, 2003: 1).

For the purpose of this study, senior generation owner-managers are those member(s) of the senior or retiring family generation, in most instances the founders of the family business who are its current executive managers.

For the purposes of this study, the readiness of the senior generation owner-manager to transfer the business to the younger generation family members includes, inter alia, the following aspects: estate planning, retirement planning, the perceived liquidity of the business after transfer, the perceived suitability of the prospective successor, and the expected outcome of the succession.

\subsection{Dependent variable}

\section{Senior generation owner-manager readiness}

to let go

The single most important factor in the successful transition of a family business to the younger generation is the attitude of the person sitting in the executive manager's seat, i.e. the senior generation owner-manager (Aronoff, 2003: 2). It is important that the owner-manager not only feels ready to transfer the business to the younger generation family members, but also perceives himself as creating a meaningful life after retirement (Aronoff, 2003: 41).

Voeller, Fairburn and Thompson (2002: 28) confirm that retirement or stepping down requires the ability to find meaning in life after giving up the challenge, influence, status, identity, control and daily structure associated with running a business. It is important for retiring owner-managers to replace negative images of retirement with more realistic, positive ones (Aronoff, 2003: 42).

Lansberg (1999: 271) claims that most family business owner-managers lack a clear vision of their lives in retirement. Successful retirement means different things to different people (Aronoff, 2003: 44). Aging owner-managers should thus be encouraged to earnestly think about what they will do once they have stepped down (Robberts, 2006: 58). Owner-managers who develop strong interests and activities other than the management of the family business generally find planning their succession easier, and are less reluctant to hand over the business to their successor (Venter \& Boshoff, 2007: 52).

As retirement is generally a difficult issue for senior generation owner-managers, it could be helpful if they developed outside interests to ease themselves into retirement (Donchels \& Lambrecht, 1999; Matthews et al., 1999; Sharma, 1997). For some owner-managers, this may even mean pursuing a new career outside the business.

Venter and Boshoff (2007: 52) add that, rather than seeing elder leaders off into a carefree retirement, family businesses are increasingly finding new roles for them, whether outside or inside the business. If the owner-manager does stay on in the family business after retirement, it 
is critical that the new role be well-defined and that it excludes participation in the day-to-day running of the business.

For the purposes of this study, the senior generation owner-manager's readiness to let go was measured by an eight-item scale, which refers to whether:

- the senior generation executive manager feels increasingly that his/her direct involvement in the family business is not crucial to its survival;

- the senior generation executive manager is willing to delegate authority to younger family members;

- the senior generation executive manager will be financially secure after his/her retirement;

- the senior generation executive manager talks with other businessmen who are also in the process of transferring management of their family business to the younger family members;

- the senior generation executive manager will be willing to relinquish control of the family business;

- the senior generation executive manager has passionate interests outside the family business to fill his/her time after retirement (hobbies, sport and other interests);

- the senior generation executive manager is involved in activities outside the context of the family business; and

- the senior generation executive manager feels that the younger family members are capable of managing the family business after his/her retirement.

\subsection{Independent variables}

\section{Estate planning}

Inadequate estate planning or the lack of written estate plans and wills could be obstacles to succession, because the senior generation needs to feel financially secure before relinquishing control to the younger generation (Ryan, 1995: 13).

Estate planning is the general term that describes the development and implementation of strategies pertaining to the transfer, management and perpetuation of an individual's or a family's assets from one generation to the next (Rawls, 1999: 68). Jaffe (1991: 217) defined estate planning as planning for the family's future by creating an estate plan that implements the owner's wishes for how the business and other inheritance will be passed along to the family and other heirs.

The importance of estate planning as a critical part of the succession process is well documented in family business literature (see for example Venter \& Boshoff, 2007: 44; Bjuggren \& Sund, 2001; Hume, 1999; Sturgill, 1998). Ryan (1995: 13) concurs that estate planning by the family business members is an important element in ensuring the continuity of the business. Venter and Boshoff (2007: 44) refer to a study by File and Prince (1996) on family businesses that failed, which demonstrated that inadequate estate planning was associated more often with family business failure than poor management succession planning. According to Venter and Boshoff (2007: 44), it is clear that a large volume of evidence in the literature supports the view that estate planning impacts positively on the success of the succession process.

Estate planning comes down to a single key aspect, namely how the family and business can be left in the best possible financial shape after succession (Voeller et al., 2002: 79). Bork, Jaffe, Lane, Dashew and Heisler (1996: 199) emphasised that estate planning involves the compilation of documentation that directs the transfer of property from owners to others in the most tax-efficient manner.

Emens and Wolper (2000: 46) emphasise that family business owners should review their latest trusts and wills to ensure that all major changes have been taken into account. Documents relating to any changes in legislation should be amended. Shanoff (2006: 22) confirms that successful estate planning involves explicit written directions on who gets what. Estate planning in the business succession realm is a formidable challenge demanding significant commitments of time, energy and financial resources (Rawls, 1999: 72).

Aronoff and Ward (2001: 24) suggested that one of the major problems with estate planning as far as business owners are concerned is that 
they feel they have increasingly less control over their own destiny. They are thus reluctant to plan. Failure to plan often aggravates this feeling (Jaffe, 1991: 223). However, completed, known estate plans are a pre-condition for sibling team success and family harmony (Aronoff, Astrachan, Mendoza \& Ward, 1997: 47).

For the purposes of this study, the independent variable estate planning was measured by a nineitem scale. It refers to whether:

- there are written decisions on the distribution of the family assets and ownership to the younger generation after retirement of the senior generation family members;

- the goals of the estate plan are known to the family;

- the estate plan addresses future claims against the estate;

- the senior generation family members have signed wills that have been reviewed and updated during the past two years;

- the estate plan addresses the implications of the current and the heir's future form of enterprise;

- the senior generation family members have written estate plans that meet the unique needs of the family business;

- the estate plan provides in the case of disability of the senior generation family members;

- there is provision in the estate plan for threats such as divorce, the matrimonial property system and insolvency; and

- the estate plan meets the requirements for minimising estate tax.

\subsection{Retirement planning}

Friedman (1998: 132) emphasises that no estate plan is complete without the inclusion of an acceptable retirement plan. One reason why owner-managers are reluctant to retire is that they have not figured out how to continue their standards of living without the annual salaries from the business (Rivers, 2005: 116). Aronoff (2003: 9) is of the opinion that what often keeps a senior generation owner-manager from letting go is the need for security, including financial security. Aronoff (2003: 25) further emphasised that a key to effective succession is proactive planning to provide lifetime financial security for the senior generation.

The mere fact that a senior member retires from the business does not mean that $\mathrm{s} / \mathrm{he}$ no longer has expenses. Potts, Schoen, Loeb and Hulme (2001: 86) urge that ensuring financial stability is a critical issue when owner-managers consider withdrawing from the family business. In order to put together a sound plan for retirement, they need to know their financial needs after retirement (Voeller et al., 2002: 28). Swart (2005a: 74) stressed that, once the senior generation owner-managers have developed a vision for the future, they can begin planning to ensure financial security to live their dream.

Potts et al. (2001: 87) caution that a lower standard of living may have a deeper impact on retirees than the actual loss of material comfort. For this reason, concern with maintaining an acceptable lifestyle may affect the ability of the retiree and his/her spouse to accept their new self-image and new identities. Furthermore, a lack of understanding of what the retiring leader is going through augments the psychological resistance to retirement planning (Lansberg, 1999: 274). Those who have spent their lifetime building and running a business usually find it very difficult to let go when the time comes to hand over the reigns to somebody else (Lansberg, 1999: 250; Lea, 1991: 143).

For the purposes of this study, the independent variable retirement planning was measured by a seven-item scale and refers to whether

- sufficient retirement packages are available to the senior generation family members in the family business;

- the senior generation family members have determined their expected current and future lifestyle expenditures;

- sufficient provision has been made for the senior generation family members to be financially secure after retirement;

- the senior generation family members will be financially dependent on the family business after retirement;

- the retirement programme of the family business is adequately funded; 
- the family business has a financial system in place that ensures the financial independence of its retirees; and

- the existing capital available to the senior generation family members will generate the income and cash flow to meet their expenditure requirements for the remainder of their lifetimes.

\subsection{Perceived liquidity of the business after transfer}

According to Short, Libby and Libby (2007: 724), the word 'liquid', within the context of how liquid a business is, means the ability of a business to meet its currently maturing debts. Megginson, Smart and Graham (2010: 41) defined liquidity as the term used to indicate a firm's ability to satisfy its short-term obligations as they come due. For the family business, it is important to turn an investment or asset into cash quickly (Aronoff \& Ward, 2002: 25).

Swart (2005a: 75) emphasised that too few family business owners have an accurate idea of how much it would cost to settle their estate, or when the taxes and other expenses must be paid (Emens \& Wolper, 2000: 46). De Visscher, Aronoff and Ward (1995: 4) noted that many family businesses failed because capital or liquidity problems prevented them from surviving generational, strategic or ownership transitions. Even though the estate tax laws contain special provisions allowing for delayed payment in some cases, it is vital to focus on liquidity needs (Emens \& Wolper, 2000: 46).

Some of the expenses requiring cash from the estate's fiduciary include income taxes, probate and administration costs, payment of any maturing debts, funds to continue the operation of the family business, and payment for mistakes while new management is learning the business (Swart, 2005a: 75, 76; Emens \& Wolper, 2000: 46).

Senior generation owner-managers should therefore give thought to liquidity; that is, how business assets can be converted to cash to fulfil the desires of the individual owners who want to redeem their shares and how profits will be used (Swart, 2005b: 106; Aronoff \& Ward, 2002: 28).
For the purposes of this study, the independent variable, perceived liquidity of the business after transfer, refers to whether:

- the family business will be financially secure after the retirement of the senior generation family members;

- sufficient capital will be available to successfully manage the family business after the retirement of the senior generation family members;

- the financial retirement needs of the senior generation family members would put the family business under financial strain; and

- the liquidity of the estate when senior generation family members pass away has been determined.

This independent variable was measured according to a four-item scale.

\subsection{Suitability of the prospective successor}

Reluctance on the part of the senior generation owner-manager to let go of the business may be underpinned by feelings of doubt about the successor's ability, willingness and desire to take control (Goldberg \& Wooldridge, 1993: 70). Trust in the successor's ability to manage the family business is important as far as the succession process is concerned, as it may affect the incumbent's willingness to hand over the business to the successor (Venter, 2003a: 186; Dickenson, 2000: 37; Donchels \& Lambrecht, 1999: 177).

It is necessary for the founder to plan to disengage from the business, but this alone is not sufficient to ensure a successful transition. The other ingredient is a competent replacement (Dyer, 1986: 126). The development of capable successor managers is a critical factor in family business succession (Rawls, 1999: 179).

Voeller et al. (2002: 79) recommend that the start would be determining what kind of leadership (entrepreneurial or managerial) the business needs for the years ahead and then defining what specific qualities and skills the type of leader would require. Rawls (1999: 180) concurs with this first step, maintaining that the core set of skills is similar across various 
industries. It is crucial to have a match between the competences, experience and leadership of the prospective successor and the future leadership requirements of the family business. Any gaps should be identified and closed either by developing the successor or by employing non-family professional management.

Ensuring a smooth transfer of the business requires the next generation to gain acceptance, credibility and legitimacy among the ownermanager, other family members and nonfamily members. The development of the successor should be negotiated up front with the successor in order to identify specific skills and competencies that have to be met at every stage of the succession process prior to moving to the younger stage and eventually the final transfer of the business to them (Lansberg, 1999: 182; Neubauer \& Lank, 1998: 150).

For the purposes of this study, the suitability of the prospective successor refers to whether the prospective successor(s):

- possess(es) the necessary skills to ensure the success of the family business after succession;

- has/have the necessary leadership skills to manage the family business after the transfer of management;

- believe(s) in his/her ability to successfully manage the family business;

- possess(es) the necessary knowledge and experience to ensure the success of the family business after succession; and

- represent(s) a good fit between the skills and knowledge of the prospective successor(s) and what is needed for the family business to succeed.

This independent variable was measured by a five-item scale.

\subsection{Expected outcome of the succession}

Grassi and Giarmarco (2008: 27) indicated that one of the main concerns facing family business owners is how to bring about an orderly and affordable succession of the business. Monetary losses and loss of the business could occur if there was no proper plan for smooth succession during the owner's lifetime.

Well-diversified and high degrees of success are necessary to provide both the motivation and the momentum to achieve success (Rawls, 1999: 172). A great succession is one hardly anybody notices and good succession planning also enhances the value of the business (Aronoff \& Ward, 1992: 3). Success is actualised through high achievement in a broad base of success factors (Rawls, 1999: 172).

Success factors of succession include the following:

- The family business performs equally well after succession;

- The employees of the family business support the successor once the leadership has been transferred to him/her;

- It is possible to maintain the existing contracts and client base after succession;

- Family relationships remain good after succession; and

- All family members support the successor once the leadership has been transferred to him/her (Swart, 2005b: 96; Venter, 2003a; Rawls, 1999: 72).

This independent variable was measured by a five-item scale.

\section{5 \\ Research methodology}

\subsection{The measuring instrument}

In order to operationalise the variables, a measuring instrument should be constructed. In this study, the measuring instrument consisted of variables and items whose reliability and validity have been confirmed in previous studies (Venter, 2003a; Sharma, 1997; File \& Prince, 1996). When publicised items were not available, self-developed items were used. For the purpose of this study, five latent variables were identified to measure the dependent variable, the readiness of the senior generation owner-manager to let go (Read). These are: estate planning (EP), retirement planning (Ret), perceived liquidity of the business after transfer (Liq), perceived 
suitability of the successor (Suit) and expected outcome of succession (Out). A comprehensive measuring instrument was developed to measure the latent variables.

The measuring instrument was developed in three phases:

- The items for measuring each latent variable were formulated after a comprehensive review of the family business literature.

- The instrument was then tested at a single family business, after which the instrument was piloted at nine family businesses, with 71 family members who completed the pilot questionnaires.

- The measuring instrument was then refined after each phase, followed by the drafting of an adapted version of the instrument.

The third version of the measuring instrument (used in this study) assessed the six latent variables with 38 statements on the basis of a seven-point Likert-type scale ranging from 'Strongly disagree' (1) to 'Strongly agree' (7).

\subsection{The study population}

The target population of this study was small and medium-sized family businesses in South Africa. Numerous attempts were made to secure a database of family businesses in South Africa, but to no avail. It was therefore decided to use a convenience sample, by means of the snowball sampling technique, to identify the family businesses that participated in this study (Page \& Meyer, 2000: 100).

To generate a preliminary list of family businesses, well-known business people were contacted in various regions of South Africa. These business people then acted as informants and identified potential family businesses for inclusion in the sample. The latter then identified a further set of family businesses. These referrals were subsequently contacted telephonically to confirm that they fulfilled the definition of small- and medium-sized family businesses used in this study (Ibrahim \& Ellis, 2004: 5; National Small Business Amendment Act, 2004: 2; National Small Business Act, 1996) and to gauge their willingness to participate in the study. A list of 185 family businesses willing to participate in the study was compiled as a result of these efforts.

The sampling technique and methodology are consistent with those of other family business researchers who have been constrained by the lack of a national database on family businesses (Eybers, 2010; Farrington, 2009; Van der Merwe \& Ellis, 2007; Sonfield \& Lussier, 2004; Venter, 2003a).

\subsection{Data collection}

Family businesses listed on the database were subsequently contacted to identify the individual family members in the particular family based on the family tree. Questionnaires were then mailed to these family members. Each questionnaire was sent with a covering letter that guaranteed the confidentiality of the responses, as well as a return-paid envelope in order to make it as easy as possible for respondents to take part in the research. A total of 504 usable questionnaires were returned from 81 family businesses, which were subjected to further statistical analysis.

\subsection{Statistical analysis}

The initial step in the data analysis was to assess the discriminant validity of the measuring scale used to measure the latent constructs in the theoretical model. This was done using the multivariate technique of exploratory factor analysis, with the purpose of establishing which of the questionnaire items measured each construct (and only the construct) in the theoretical model. The exploratory factor analysis was conducted using the computer programme SPSS (SPSS, 2008). The reliability of the questionnaire was measured by using Cronbach's Alpha Coefficient, which is based on the average correlation of items within an instrument or scale, and is regarded as an indication of internal consistency.

The relationship between the dependent and independent variables was examined by means of multiple regression analysis. Thereafter, the relationship between the demographic variables, family employee gender and the size of the business; and the variables were explored by means of t-tests and effect sizes (SPSS, 2008). 


\section{6}

\section{Results and discussion}

\subsection{Demographic information}

The demographic information of the participating family members and businesses is presented in Table 1.

\section{Table 1}

Demographic information of the sample

\begin{tabular}{|c|c|c|}
\hline Variable & Frequency & Percentage (\%) \\
\hline \multicolumn{3}{|l|}{ Gender $(n=504)$} \\
\hline Male & 258 & 51.19 \\
\hline Female & 246 & 48.81 \\
\hline \multicolumn{3}{|l|}{ Generation $(n=298)$} \\
\hline In-laws (younger generation) & 106 & 21.03 \\
\hline Senior generation (parents) & 165 & 32.74 \\
\hline Younger generation (offspring) & 224 & 44.44 \\
\hline Other (e.g. uncles, aunts, cousins) & 9 & 1.79 \\
\hline \multicolumn{3}{|l|}{ Age category (years) $(n=298)$} \\
\hline Younger than 29 & 137 & 27.18 \\
\hline $30-39$ & 156 & 30.95 \\
\hline $40-49$ & 57 & 11.31 \\
\hline $50-59$ & 96 & 19.05 \\
\hline Older than 60 & 58 & 11.51 \\
\hline \multicolumn{3}{|c|}{ Business size (permanent employees) $(n=81)$} \\
\hline 1 - 50 (small business) & 62 & 76.54 \\
\hline 51 - 200 (medium business) & 19 & 23.46 \\
\hline
\end{tabular}

The majority of the 504 participating respondents were under the age of 40 years $(58.13$ per cent), 11.31 per cent between the ages of 40 and 49, with 30.56 per cent over the age of 50 years. Furthermore, an approximately equal distribution between male and female respondents was evident (51.19 per cent male, 48.81 per cent female). A total of 32.74 per cent of the respondents were senior generation family employees (parents), with 44.44 per cent representing the younger generation family employees (offspring). The rest of the family employees comprised in-laws (married to younger generation family members) (21.03 per cent) and other family employees, such as uncles, aunts or cousins (1.79 per cent).

A total of 17.28 per cent of the 81 family businesses who participated in this study can be categorised as micro and very small businesses in the South African context (10 employees 
and less) and 59.26 per cent small businesses (between 11 and 50 permanent employees). The rest (23.56 per cent) can be categorised as medium-sized businesses (between 51 and 200 employees).

\subsection{Construct validity of the measuring questionnaire}

According to Bless and Higson-Smith (1995: 130), it is important for researchers to evaluate the measures or instruments that they use. This can be done by evaluating, inter alia, the construct validity and reliability of measures (Page \& Meyer, 2000: 84).

Subsequently, the following two propositions were formulated:

P1: The measuring instrument has acceptable construct validity;

P2: The measuring instrument has acceptable reliability.

To assess the discriminant validity of the 38 items measuring the readiness of the senior generation owner-manager to let go, an exploratory factor analysis was conducted using the SPSS (SPSS, 2008). In this study, there was theoretical justification for believing that the factors measuring the readiness of the senior generation owner-manager to let go would correlate with each other. An Oblimin oblique rotation was performed on the principal components of the exploratory factor analysis, as suggested by Field (2009: 643). The correlation matrix for these six constructs indicates correlations of 0.101 to 0.495 between the constructs (Ellis \& Steyn, 2003: 53), confirming that an oblique rotation should have been used (Field, 2009: 643).

Kaiser's criterion was used to determine the number of factors to be extracted, namely to retain factors with eigen-values greater than one (Field, 2009: 640). All 38 items demonstrated sufficient discriminant validity by loading to a sufficient extent, so no item was deleted. The pattern matrix of the 38 items is provided in Table 2. Factor loadings greater than 0.35 were considered significant.

Table 2

Pattern matrix of Oblimin rotated-principal component factor analysis (1)

\begin{tabular}{|l|c|c|c|c|c|}
\hline \multicolumn{1}{|c|}{ Item (2) } & $\begin{array}{c}\text { Factor 1: (3) } \\
\text { Retirement } \\
\text { planning }\end{array}$ & $\begin{array}{c}\text { Factor 2: } \\
\text { Successor } \\
\text { suitability }\end{array}$ & $\begin{array}{c}\text { Factor } \\
\text { 3: Estate } \\
\text { planning }\end{array}$ & $\begin{array}{c}\text { Factor 4: } \\
\text { Owner- } \\
\text { manager } \\
\text { readiness }\end{array}$ & $\begin{array}{c}\text { Factor 5: } \\
\text { Perceived } \\
\text { liquidity }\end{array}$ \\
\hline Read3 & $\mathbf{0 . 8 7 7}$ & 0.086 & 0.028 & -0.084 & -0.019 \\
\hline Ret3 & $\mathbf{0 . 8 1 8}$ & -0.071 & -0.046 & 0.059 & -0.142 \\
\hline Ret5 & $\mathbf{0 . 8 1 3}$ & -0.013 & -0.006 & 0.034 & 0.018 \\
\hline Ret6 & $\mathbf{0 . 7 8 9}$ & -0.025 & -0.082 & 0.113 & 0.046 \\
\hline Ret1 & $\mathbf{0 . 7 5 6}$ & -0.040 & 0.005 & -0.002 & -0.081 \\
\hline Ret4 & $\mathbf{0 . 7 5 5}$ & -0.063 & 0.064 & 0.134 & -0.085 \\
\hline Ret7 & $\mathbf{0 . 7 3 8}$ & 0.071 & -0.090 & 0.009 & -0.129 \\
\hline EP7 & $\mathbf{0 . 7 1 0}$ & 0.092 & -0.195 & -0.036 & 0.245 \\
\hline EP8 & $\mathbf{0 . 5 9 8}$ & 0.063 & -0.257 & -0.074 & 0.095 \\
\hline Suit1 & -0.043 & $\mathbf{0 . 8 6 4}$ & -0.056 & -0.081 & -0.020 \\
\hline Suit3 & 0.015 & $\mathbf{0 . 8 5 0}$ & -0.046 & -0.084 & -0.063 \\
\hline Suit2 & 0.003 & $\mathbf{0 . 8 3 5}$ & 0.015 & -0.018 & -0.022 \\
\hline Sui4 & $\mathbf{0 . 8 1 6}$ & -0.013 & -0.005 & 0.075 \\
\hline
\end{tabular}


SAJEMS NS 13 (2010) No 3

\begin{tabular}{|c|c|c|c|c|c|}
\hline Out1 & 0.004 & 0.810 & 0.012 & -0.041 & -0.104 \\
\hline Out5 & -0.038 & 0.587 & -0.041 & 0.260 & 0.110 \\
\hline Suit5 & 0.183 & 0.507 & 0.093 & 0.384 & 0.050 \\
\hline Read8 & -0.126 & 0.489 & -0.206 & 0.428 & 0.058 \\
\hline Out3 & 0.121 & 0.420 & 0.108 & 0.289 & -0.173 \\
\hline EP9 & 0.045 & 0.079 & -0.770 & -0.078 & -0.101 \\
\hline EP2 & -0.142 & 0.017 & -0.704 & 0.196 & -0.231 \\
\hline Liq4 & 0.195 & 0.042 & -0.698 & -0.036 & 0.062 \\
\hline EP3 & 0.048 & -0.033 & -0.683 & 0.074 & 0.155 \\
\hline EP4 & 0.048 & 0.138 & -0.672 & 0.024 & 0.247 \\
\hline EP6 & 0.249 & -0.011 & -0.644 & 0.007 & -0.182 \\
\hline EP5 & 0.216 & -0.006 & -0.635 & -0.054 & -0.253 \\
\hline Ret2 & 0.354 & -0.181 & -0.435 & 0.202 & -0.128 \\
\hline EP1 & 0.273 & 0.145 & -0.393 & 0.209 & 0.172 \\
\hline Read7 & 0.194 & 0.025 & 0.120 & 0.779 & 0.180 \\
\hline Read6 & 0.120 & -0.008 & 0.073 & 0.737 & 0.013 \\
\hline Read4 & -0.106 & 0.081 & -0.096 & 0.671 & -0.239 \\
\hline Read2 & -0.001 & 0.072 & -0.103 & 0.665 & 0.086 \\
\hline Read5 & -0.070 & -0.028 & -0.275 & 0.578 & -0.005 \\
\hline Out2 & 0.026 & 0.392 & 0.018 & 0.053 & -0.544 \\
\hline Liq3 & 0.378 & -0.014 & 0.055 & 0.159 & -0.519 \\
\hline Liq1 & 0.252 & 0.247 & -0.224 & -0.058 & -0.505 \\
\hline Liq2 & 0.346 & 0.028 & -0.308 & 0.155 & -0.380 \\
\hline $\begin{array}{l}\text { Cronbach } \\
\text { Alpha }\end{array}$ & 0.934 & 0.902 & 0.893 & 0.798 & 0.764 \\
\hline
\end{tabular}

(1) Loadings greater than 0.35 were considered significant

(2) The items included in the factor analysis are provided in Appendix 1

(3) The five extracted factors were labelled as follows:

Factor 1: Retirement planning (retirement planning)

Factor 2: Perceived successor suitability (successor suitability)

Factor 3: Estate planning (estate planning)

Factor 4: Owner-manager readiness to let go (owner-manager readiness)

Factor 5: Perceived liquidity of the business after transfer (perceived liquidity) 
Five factors with eigen-values greater than one, explaining 62.64 per cent of the variance before rotation, were extracted in the exploratory factor analysis. After rotation, these factors could be identified as the theoretical dimensions of retirement planning (Ret), perceived suitability of the successor (Suit), estate planning (EP), owner-manager readiness to let go (Read) and perceived liquidity of the business after transfer (Liq). When factors are correlated, sums of squares of loadings cannot be added to obtain a percentage variance explained for each of the rotated factors, as in the case of uncorrelated factors (SPSS, 2008).

The Kaiser-Meyer-Olkin measure of sampling adequacy of 0.924 indicates that patterns of correlation are compact and that factor analysis should yield reliable factors (Field, 2009: 647). Bartlett's test of sphericity yielded a p-value of smaller than 0.0001 , indicating that the correlation between variables was sufficient for factor analysis.

After rotation, five of the items loaded on more than one factor (values greater than 0.35 ). The items, Suit 5 and Read 8 loaded on both the factors perceived successor suitability and ownermanager readiness to let go. The item Ret 2 loaded on both the factors retirement planning and estate planning. Furthermore, the item Out2 loaded on both the factors perceived successor suitability and perceived liquidity of the business after succession. Item Liq3 loaded on both the factors retirement planning and perceived liquidity of the business after transfer. Rather than deleting any of the items, it was decided to classify them under the factor that yielded the highest factor loading. The classification of the five items under the factors perceived suitability of the successor (Read8), estate planning (Ret2) and perceived liquidity of the business after transfer (Out2 and Liq3) respectively also has the highest interpretation value and, moreover, makes sense in practice.

Factor one, which was labelled retirement planning, was comprised of nine items. Six of the seven items that were used to measure the latent variable retirement planning (refer to Table 2) loaded on factor one. Two items, EP7 and EP8, related to estate planning were also included in factor one, being regarded by respondents as related to retirement planning. The item Read3, relating to the latent variable owner-manager readiness to succession, was also included in factor one, and was regarded by respondents as being related to that factor.

The second factor, labelled perceived suitability of the successor, also comprised nine items. All five items that were used to measure the latent variable perceived suitability of the successor (Table 2) loaded onto factor two as expected. Three expected outcome of succession items (Table 2: Out 1, Out3 and Out5) and one owner-manager readiness for succession item (Table 2: Read8) also loaded onto factor two. The respondents thus regarded these items as additional measures of the variable perceived suitability of the successor.

Regarding the third factor, labelled estate planning, seven of the nine items that were used to measure the latent variable estate planning loaded onto this factor. One perceived liquidity of business after succession item (Table2: Liq4) and one item measuring the latent variable retirement planning (Table 2: Ret2) also loaded onto factor three. These two items were thus regarded by respondents as additional estate planning measures.

Five of the eight items used to measure the latent variable owner-manager readiness for succession (Table 2: Read2, Read4, Read5, Read6, Read7), loaded onto factor four, as expected. Factor 4 was labelled owner-manager readiness to let go.

Three of the four items used to measure the latent variable perceived liquidity of the business after succession (Table 2: items Liq 1, Liq2 and Liq3) loaded onto factor five. One expected outcome of the succession (Table 2: Out3) also loaded onto factor five, being regarded by respondents as related to equity ownership. Factor 5 was labelled perceived liquidity of the business after transfer.

From the factor loadings it is clear that all five items used to measure the latent variable expected outcome of the succession (refer to Appendix 1) were incorporated into other factors (Table 2).

The wording of the statements (items) measuring the six latent variables is provided in Appendix 1. The exploratory factor analysis, 
together with the interpretability of the factors, provides some evidence of construct validity, indicating that Proposition 1 can be accepted.

\subsection{Reliability of the questionnaire}

In order to assess the internal consistency between the items of the measuring questionnaire, Cronbach alpha coefficients were calculated (Page \& Meyer, 2000: 292). The Cronbach alpha coefficient is based on the average correlation of variables within a construct (SAS Institute 2005: 295). The greater the Cronbach alpha coefficient, the more reliable the scale. Nunnally and Bernstein (1994: 265) suggest that for acceptable reliability the Cronbach alpha coefficient should be greater than 0.7 .

All 504 participants' responses were used to determine the reliability of the extracted factors (refer to Table 2). The results indicate that the questionnaire used in this study to measure management succession planning has acceptable reliability, with no factors with a Cronbach Alpha value below the customary cut-off value of 0.70 suggested for internal consistency (Nunnally \& Bernstein 1994: 265). Proposition 2 can thus be accepted.

\subsection{Relationship between the variables}

In order to determine whether the variables retirement planning, perceived successor suitability, estate planning and perceived liquidity of the business after succession have an influence on the readiness of the senior generation owner-manager to let go, a multiple regression analysis was performed. Factor scores for each participant were computed as the average of all items contributing to the relevant factor, automatically replacing missing values by mean substitution.

The scores of family members belonging to a specific family can be considered to be dependent on that family's situation. As independence of data is one of the assumptions of linear regression, the average counts for each of the 81 families were taken as data points in a multiple regression analysis. The following propositions were formulated:

P3: There is a positive relationship between the variables retirement planning and the readiness of the senior generation ownermanager to let go.

P4: There is a positive relationship between the variables perceived for successor suitability and the readiness of the senior generation owner-manager to let go.

P5: There is a positive relationship between the variables estate planning and the readiness of the senior generation owner-manager to let go.

P6: There is a positive relationship between the variables perceived liquidity of the business after transfer and the readiness of the senior generation owner-manager to let go.

The results of the multiple regression analysis for the impact of the independent variables on the readiness of the senior generation ownermanager to let go are given in Table 3. A normal probability plot on the residuals of this fit confirmed the assumption of normality.

\section{Table 3}

Multiple regression results: impact of independent variables on the dependent variable, the readiness of the senior generation owner-manager to let go

\begin{tabular}{|l|c|c|c|c|c|}
\hline \multirow{2}{*}{ Model } & \multicolumn{2}{|c|}{$\begin{array}{c}\text { Non-standardised } \\
\text { coefficients }\end{array}$} & $\begin{array}{c}\text { Standardised } \\
\text { coefficients }\end{array}$ & \multirow{2}{*}{ t-value } & p-level \\
\cline { 2 - 6 } & B & Std. error & Beta & 2.608 & $0.010^{* *}$ \\
\hline Constant & 0.663 & 0.254 & & 5.698 & $0.000^{* *}$ \\
\hline Retirement planning & 0.330 & 0.058 & 0.331 & 6.195 & $0.000^{* *}$ \\
\hline Successor suitability & 0.286 & 0.046 & 0.319 & 3.772 & $0.023^{* *}$ \\
\hline Estate planning & 0.209 & 0.055 & 0.196 & 1.598 & 0.111 \\
\hline Perceived liquidity & 0.064 & 0.040 & 0.080 & & \\
\hline
\end{tabular}

$\mathrm{R} 2=0.613(* * \mathrm{p}<0.05)$ 
Table 3 indicates that, in practice, a significant percentage (61.3 per cent) of the variation in the readiness of the senior generation owner-manager to let go is explained by the variables retirement planning, successor suitability, estate planning and the perceived liquidity of the business after succession. The positive regression coefficients indicate that the readiness of the owner-manager to let go is related to retirement planning, successor suitability, estate planning and the perceived liquidity of the business after succession.

The contribution of retirement planning, successor suitability and estate planning is statistically significant for the prediction of the readiness of the owner-manager to let go. Proposition 3, Proposition 4 and Proposition 5 can thus be accepted. In other words, the more retirement and estate planning take place and the better the perceived suitability of the successor, the better the readiness of the owner-manager to let go will be. No statistically significant relationship could be found between the perceived liquidity of the business after transfer and the readiness of the owner manager to let go. Proposition 6 is thus rejected.

\subsection{Comparing the mean differences between variables for demographic variables}

An advantage of drawing a random sample is that it enables one to study the properties of a population with the time and money available (Ellis \& Steyn, 2003: 51). In such cases the statistical significance tests (e.g. t-tests) are used to show that the results of the difference between two means are significant. The authors indicated that the $p$-value is a criteria of this, giving the probability that the obtained value or larger could be obtained with the assumption that the null hypothesis (e.g. no difference between the means) is true.

A small $p$-value (e.g. smaller than 0.05) is considered to be sufficient evidence that the result is statistically significant. Statistical significance, however, does not necessarily imply that the result is important in practice, as these tests have the tendency to yield small $p$-values (indicating significance) as the size of the dataset increases (Ellis \& Steyn, 2003: 51).
Data obtained from convenience sampling are, according to Ellis and Steyn (2003: 51), often erroneously analysed as if they had been obtained by random sampling. These data should be considered as a small population for which statistical inference and $p$-values are not relevant. Statistical inference draws conclusions about the population from which a random sample was drawn, using the descriptive measures that have been calculated. Instead of merely reporting descriptive statistics, effect sizes can be determined. The effect size is independent of sample size and is a measure of practical significance (Ellis \& Steyn, 2003: 51). Although the results of the t-test will be discussed, the findings of this study resulting from the use of a convenience sample method will be based on the effect sizes ( $d$-values).

The following propositions were formulated:

P7: There is a difference between the ways in which the male and female family members perceive the variables, i.e. retirement planning, perceived suitability of the successor, estate planning, owner-manager readiness to let go and perceived liquidity of the business after transfer.

P8: There is a difference between the ways in which the senior and younger generation family members perceive the variables, i.e. retirement planning, perceived suitability of the successor, estate planning, ownermanager readiness to let go and perceived liquidity of the business after transfer.

P9: There is a difference between the ways in which family members employed by small and medium-sized family businesses perceive the variables retirement planning, perceived suitability of the successor, estate planning, owner-manager readiness to let go and perceived liquidity of the business after transfer.

The differences between the means of the variables (see Table 2) for the demographic variable gender (male and female) and generation (senior and younger) of the participating family members were examined by paired t-tests and effect sizes ( $d$-values), because the responses of members of the same family can be considered to be dependent. The analysis was performed 
at the family level, where the average scores for each of the 81 families were taken as data points. However, the difference between the means of the variables for small and medium-sized businesses will be examined by independent t-tests and effect sizes.

These effect sizes $(d)$ will be interpreted according to Cohen's guidelines, as follows: small effect $(d=0.2)$, medium effect $(d=0.5)$ and large effect $(d=0.8)$. Results with medium effects can be regarded as visible effects and with $d \geq 0.8$ as practically significant, since it is the result of a difference having a large effect (Field, 2009: 57; Ellis \& Steyn, 2003: 51-53; Thompson, 2001: 80-93; Cohen, 1992: 155-159).

Table 4 shows the relationships between the five variables and the demographical variables gender, generation and business size respectively, with the mean $(\bar{x})$, standard deviation $(s)$, t-tests ( $p$-value) and effect sizes (d-value).

Table 4

The results of the differences between the means of the variables for different demographic variables

\begin{tabular}{|c|c|c|c|c|c|c|c|c|}
\hline \multicolumn{9}{|c|}{ Gender } \\
\hline \multirow[t]{2}{*}{ Variable } & \multicolumn{3}{|c|}{ Male } & \multicolumn{3}{|c|}{ Female } & \multicolumn{2}{|c|}{ Comparison } \\
\hline & $\mathbf{n}$ & $\bar{x}$ & $s$ & $\mathbf{n}$ & $\bar{x}$ & $S$ & $p$ & d \\
\hline Retirement planning & 57 & 4.34 & 1.19 & 57 & 4.30 & 1.51 & 0.063 & 0.25 \\
\hline Successor suitability & 57 & 5.72 & 0.77 & 57 & 5.55 & 0.93 & 0.216 & 0.17 \\
\hline Estate planning & 57 & 4.49 & 0.96 & 57 & 4.35 & 1.30 & 0.380 & 0.13 \\
\hline Owner-manager readiness & 57 & 4.90 & 0.98 & 57 & 4.68 & 1.41 & 0.204 & 0.20 \\
\hline Perceived liquidity & 57 & 5.33 & 0.75 & 57 & 5.08 & 1.11 & 0.048 & 0.27 \\
\hline \multicolumn{9}{|c|}{ Family generation } \\
\hline \multirow[t]{2}{*}{ Variable } & \multicolumn{3}{|c|}{ Senior } & \multicolumn{3}{|c|}{ Younger } & \multicolumn{2}{|c|}{ Comparison } \\
\hline & $\mathbf{n}$ & $\bar{x}$ & $s$ & $n$ & $\bar{x}$ & $S$ & $p$ & d \\
\hline Retirement planning & 80 & 4.44 & 1.40 & 80 & 4.46 & 1.32 & 0.854 & 0.02 \\
\hline Successor suitability & 79 & 5.72 & 0.92 & 79 & 5.58 & 0.88 & 0.223 & 0.14 \\
\hline Estate planning & 80 & 4.90 & 1.18 & 80 & 4.32 & 1.20 & 0.000 & 0.51 \\
\hline Owner-manager readiness & 79 & 5.26 & 1.01 & 79 & 4.57 & 1.37 & 0.000 & 0.54 \\
\hline Perceived liquidity & 80 & 5.48 & 0.90 & 80 & 5.25 & 1.09 & 0.044 & 0.23 \\
\hline \multicolumn{9}{|c|}{ Business size } \\
\hline \multirow[t]{2}{*}{ Variable } & \multicolumn{3}{|c|}{ Micro \& small } & \multicolumn{3}{|c|}{ Medium-sized } & \multicolumn{2}{|c|}{ Comparison } \\
\hline & $\mathbf{n}$ & $\bar{x}$ & $s$ & $n$ & $\bar{x}$ & $s$ & $p$ & d \\
\hline Retirement planning & 62 & 4.25 & 1.25 & 18 & 5.01 & 1.25 & 0.026 & 0.61 \\
\hline Successor suitability & 62 & 5.64 & 0.67 & 18 & 5.77 & 0.81 & 0.486 & 0.16 \\
\hline Estate planning & 62 & 4.48 & 1.00 & 18 & 4.86 & 1.05 & 0.170 & 0.36 \\
\hline Owner-manager readiness & 62 & 4.80 & 0.99 & 18 & 5.28 & 0.91 & 0.073 & 0.48 \\
\hline Perceived liquidity & 62 & 5.16 & 0.90 & 18 & 5.81 & 0.67 & 0.006 & 0.72 \\
\hline
\end{tabular}


The results indicated a statistically significant difference $(p<0.05)$ in the mean values between the ways in which males and females perceive only one variable, perceived liquidity of the business after transfer $(p=0.048)$. Although the average scores for male family employees were higher than those for female family employees, it could not be regarded as a practically significant difference between the ways in which male and female family employees perceived the liquidity of the business after transfer. Based on Cohen's guidelines (Ellis \& Steyn, 2003: 51-53; Cohen, 1992: 155-159), Proposition 7 cannot be accepted.

Although a statistically significant difference between the mean values relating to the senior and younger generation family employees regarding the variables estate planning $(p<$ $0.001)$, owner-manager readiness $(p<0.001)$ and perceived liquidity of the business after succession $(p=0.044)$, the differences yielded only medium to small effect sizes $(d=0.51 ; d=0.54$ and $d=0.23$ respectively). The results indicate that, although the average scores for senior generation family employees are higher than those for younger generation family employees, it could be regarded only as a visible difference between the ways in which senior and younger generation family employees perceived estate planning and owner-manager readiness to let go. Proposition 8 therefore cannot be accepted.

Family members employed by medium-sized family businesses, as opposed to those employed by small family businesses, rated only two variables, retirement planning $(p=0.026)$ and perceived liquidity of the business after transfer ( $p=0.006)$, as statistically significant, but the differences were not practically significant and only medium effects $(d=0.61$ and $d=0.72$ respectively) could be determined. It is thus clear that, although the average scores for family members employed by medium-sized family businesses are higher than those for small family businesses for all five variables, it could not be regarded as a practically significant difference between the ways in which family members employed by medium or small family businesses perceived those variables. Proposition 9 therefore cannot be accepted.

\section{7 \\ Limitations and suggestions for future research}

The study attempted to make a contribution to the body of knowledge on the emotional challenge for the senior generation ownermanager to let go of the business after succession and to allow the younger generation manager to run the business without interference. However, only some of the determinants of the readiness of the senior generation to let go were assessed, so the study should be regarded as exploratory. Other determinants, such as, inter alia, the senior owner-managers' age, health, and other business opportunities or commitments, were excluded from this study. More comprehensive research is still needed to clarify all the underlying dimensions of the letting-go challenge in family businesses to enhance our understanding of these issues.

Although family businesses from all the South African provinces participated in this study, it cannot be considered representative of all small and medium-sized family businesses in South Africa as a whole, owing to the use of the convenience sampling technique. Care should therefore be exercised in the interpretation and utilisation of the results, and the findings of the study cannot be generalised. In other words, the typical family business could be underrepresented in the sample.

The exploratory factor analysis in the study provides some evidence of construct validity, but further research is needed before the measuring instrument can be utilised to diagnose these issues in small and mediumsized family businesses. It is recommended that more advanced statistical procedures for scale validation, such as structural equation modelling, should be used, and that there should be further development of the questionnaire. Supplementary research on the use of the measuring instrument is also necessary to refine its norms.

Based on the fact that both national and international published evidence of a quantitative nature (premised on empirical evidence of the determinants of the readiness of 
the senior generation owner-manager to let go after succession) relating to small and mediumsized family businesses is altogether absent, the findings of this study present challenges for further research.

A limitation is that this study relied completely on the respondents' perceptions. To close the gap between perception and reality, future research could be designed for collecting field data on the emotions of all the stakeholders during the process of transferring the business to the younger generation of family members. In-depth interviews with those involved in the transfer could further contribute to the understanding of the dynamics and underlying processes of the final stage in the management succession process in family businesses, i.e. the transfer of the management and eventual ownership to the younger generation family members (refer to Venter \& Boshoff, 2007: 52).

\section{8}

\section{Managerial implications and recommendations}

The study's findings are useful from both the theoretical and the managerial perspectives. A senior generation owner-manager's decision about letting go affects many people, which has repercussions for the letting-go decision (Aronoff, 2003: 33). Further, the authors stressed that constant communication over time is essential to the letting-go process. It is thus recommended that family members discuss this issue during regular family forums (Aronoff, 2003: 5).

It is important for all the stakeholders in the succession process to understand the emotional struggle of the senior generation owner-manager to let go of the control of the family business. During family forum meetings, discussing the process of finally transferring the business to the younger generation can also play a pivotal role in guaranteeing that all the role-players gain insight into the emotions and complexity of the letting-go process, which could ensure a smooth transfer of the management and ownership of the family business to the younger generation family members in the future.

Based on the literature review and the findings of the empirical study, the following practical recommendations could mean a smooth transfer of the management and eventually ownership of the business to the younger generation family members:

- The family business should make sufficient provision for the financial security of the senior generation family members after retirement.

- The family should start at an earlier stage to prepare and develop the prospective successor for successfully managing the family business after transfer.

- Senior generation owner-managers should develop interests outside the family business and create quality of life instead of only quality of work life.

- A financial advisor should assist the family in the succession process when estate planning is discussed and to mentor the ownership succession transfer from the senior to the younger generation. The liquidity of the business after transfer should also be assessed and planned.

It is further recommended that, rather than seeing senior generation owner-managers off into a carefree retirement, family businesses should find new roles for them, either outside or inside the business. Should the owner-manager stay on in the family business after retirement, it would be critical for the new role to be well-defined and to make sure that it did not include participation in the day-to-day running of the business.

9

\section{Conclusions}

This study confirms the importance of the readiness of the senior generation ownermanager to transfer the management and ownership of the business to the younger generation family members if a successful succession is to be effected (Venter et al., 2003a: 3; Sharma et al., 2000: 236; Matthews et al., 1999: 163). It also reports some evidence of construct validity and reliability of an instrument in measuring these determinants. 
Five factors describing the theoretical dimensions of retirement planning, perceived suitability of the successor, estate planning, ownermanager readiness to let go and perceived liquidity of the business after transfer (see Table 2) were extracted. The correlation matrix for the five extracted factors indicates correlations of 0.189 , $0.260,0.321,0.435,0.446$ and 0.501 respectively between the five variables, confirming that an oblique rotation should be used (Field, 2009: 644; Ellis \& Steyn, 2003: 53).

The findings of the literature study indicated that the following aspects could have an influence on the readiness of the senior manager to finally transfer the business to the younger generation family members, i.e. sufficient provision and planning for the financial security of the retired senior generation (Friedman, 1998: 132; Lansberg, 1999: 250; Potts et al., 2001: 86); the senior generation owner-manager's perceptions regarding the suitability of the prospective successor to successfully manage the business after succession (Venter 2003a: 186; Dickenson, 2000: 37; Donchels \& Lambrecht, 1997: 177; Goldberg \& Woolridge, 1993: 70); estate planning (Venter \& Boshoff, 2007: 44; Bjuggren \& Sund, 2001; Ryan, 1995: 13) and the perceived liquidity of the business after transfer (Swart, 2005a: 75; Swart, 2005b: 106; Aronoff \& Ward, 2002: 28; Emens \& Wolper, 2000: 46; De Visscher et al., 1995: 4)

The empirical findings of this study indicate a positive relationship between the dependent variable, the readiness of the owner-manager to let go, and the independent variables, retirement planning, estate planning and the perceived suitability of the successor. In other words, the more retirement and estate planning take place and the better the perceived suitability of the successor, the greater the readiness of the owner-manager to let go. The findings thus confirm the literature.

Contrary to the findings in literature study, no significant relationship could be found between the readiness of the owner-manager to let go and the perceived liquidity of the business after succession. It is suggested that these relationships be further investigated in future research to improve our understanding of the relationships in practice.
The senior generation family members are visibly (medium effect) more positive about estate planning and their own readiness to relinquish control of the business. The reason for these visible effects might be that senior generation family employees, in this case still the owner-managers, feel themselves to be more in control of the succession process in the family business. The prospective successors, on the other hand, often feel excluded from those processes.

This study provides evidence that family members involved in medium-sized family businesses tend to be visibly (medium effect) more positive about retirement planning and the perceived liquidity of the business after its transfer to the younger generation, in comparison with family members in small businesses. This makes sense in practice, because bigger businesses should have more capacity - finances and competences - in order to absorb the burden and cost of retirement and estate planning.

No practically significant differences could be found between the means of the demographical variables gender (male and female), family generation (senior and younger) and business size (small and medium) regarding any of the constructs measuring the readiness of the senior generation owner-manager to finally transfer the business to the younger generation.

Although the acceptance of propositions P7, P8 and P9 was based on Cohen's guidelines (Cohen, 1992: 155-159), it is important to take note of Thompson's argument (Thompson, 2001: 80-93) against using Cohen's guidelines in an overly rigid manner to interpret the differences between means of variables. Consequently, more empirical research is needed to further examine these differences and to establish norms for future interpretation.

In conclusion, both the thought of letting go and the process itself introduce feelings of grief and mourning that are natural and appropriate to one of life's major passages. Letting go is, furthermore, an inner process that requires developing a great deal of mental and spiritual strength, so that individuals can separate their identity from that of the business and understand that they are two separate entities (Aronoff, 2003: 61, 62). 


\section{References}

ACKERMAN, R. 2001. Hearing grasshoppers jump: the story of Raymond Ackerman as told to Denise Prichard, Claremont: David Philip.

ADENDORFF, C.M. 2004. The development of a cultural family business model of good corporate governance for Greek family businesses in South Africa , unpublished doctoral thesis, Rhodes University, Grahamstown, South Africa.

ARONOFF, C.E. 2003. Letting go: Preparing yourself to relinquish control of the family business, Marietta, GA: Family Enterprise Publishers.

ARONOFF, C.E., ASTRACHAN, J.H., MENDOZA, D.S. \& WARD, J.L. 1997. Making sibling teams work: the next generation, Marietta, GA: Family Enterprise Publishers.

ARONOFF, C.E. \& WARD, J.L. 1992. Family business succession: The final test of greatness, Marietta, GA: Business Owner Resources.

ARONOFF, C.E. \& WARD, J.L. 2001. Family business values: how to assure a legacy of continuity and success, Marietta, GA: Family Enterprise Publishers.

ARONOFF, C.E. \& WARD, J.L. 2002. Family business ownership: how to be an effective shareholder, Marietta, GA: Family Enterprise Publishers.

ASTRACHAN, J.H. \& SHANKER, M.C. 2003. Family businesses' contribution to the U.S. economy: a closer look, Family Business Review, 16(3): 211-219.

BASU, A. 2004. Entrepreneurial aspirations among family business owners: an analysis of ethnic business owners in the UK, International Journal of Entrepreneurial Behaviour and Research, 10(1/2): 12-33. BIRD, B., WELSH, H., ASTRACHAN, J.H. \& PISTRUI, D. 2002. Family business research: the evolution of an academic field, Family Business Review, 15(4): 337-350.

BJUGGREN, P. \& SUND, L. 2001. Strategic decision making in intergenerational successions of smalland medium-sized family-owned businesses, Family

Business Review, 14(1): 11-23.

BLESS, C. \& HIGSON-SMITH, C. 1995.

Fundamentals of social research methods: an African perspective ( $2^{\text {nd }}$ ed.) Cape Town: Juta.

BORK, D., JAFFE, D.T., LANE, S.H., DASHEW, H. \& HEISLER, Q.G. 1996. Working with family businesses: a guide for professionals, San Francisco, CA: Jossey-Bass.

BROCKHAUS, R.H. 1996. Family business in Southern-Africa: an old new frontier, Paper presented at the Ninth Annual Conference of the International Council for Small Business in Southern Africa, Nelspruit, May.
BROWN, R.B. \& COVERLY, R. 1999. Succession planning in family businesses: a study from East Anglia, U.K, Journal of Small Business Management, 37(1): 93-97.

CHRISMAN, J.J., CHUA, J.H. \& STEIER, L.P. 2003. An introduction to theories of family business, Journal of Business Venturing, 18(4): 441-448.

COHEN, J. 1992. A power primer, Psychological

Bulletin, 112(1): 155-159.

DE VISSCHER, F.M., ARONOFF, C.E. \& WARD,

J.L. 1995. Financing transitions: managing capital and liquidity in the family business, Marietta, GA: Family Enterprise Publishers.

DICKENSON, T.M. 2000. Critical success factors for succession planning in family businesses, unpublished MBA dissertation, University of the Witwatersrand, Johannesburg, South Africa.

DONCHELS, R \& LAMBRECHT, J. 1999. The reemergence of family-based enterprises in East-Central Europe: what can be learned from family business research in the Western World? Family Business Review, 12(2): 171-188.

DYER, W.G. JR. 1986. Cultural change in family firms: Anticipating and managing business and family transitions, San Francisco, CA: Jossey-Bass.

ELLIS, S.M. \& STEYN, H.S. 2003. Practical significance (effect sizes) versus or in combination with statistical significance (p-values), Management Dynamics, 12(4): 51-53.

EMENS, J.R. \& WOLPER, B.E. 2000. Family business basics: The guide to the family business financial success, New Albany, OH: AASF Publications.

EYBERS, C. 2010. Copreneurs in South African small and medium-sized businesses, unpublished M.Com.

dissertation, Nelson Mandela Metropolitan University, Port Elizabeth, South Africa.

FARRINGTON, S. 2009. Sibling partnerships in South African small and medium-sized family businesses, unpublished doctoral thesis, Nelson Mandela Metropolitan University, Port Elizabeth, South Africa. FIELD, A. 2009. Discovering statistics using SPSS. (3 ${ }^{\text {rd }}$ ed.) London: Sage.

FILE, K.M. \& PRINCE, R.A. 1996. Attributions for family business failure: the heir's perspective, Family Business Review, 9(2): 71-84.

FRIEDMAN, S.E. 1998. The successful family business, Amherst, NY: The NGP Publishers.

GOLDBERG, S.D. 1996. Research note: effective successors in family-owned businesses: significant elements, Family Business Review, 9(2): 185-197. GOLDBERG, S.D. \& WOOLRIDGE, B. 1993. Self-confidence and managerial autonomy: successor characteristics critical to succession in family firm, Family Business Review, 6(1): 55-73. 
GRASSI, S.V. \& GIARMARCO, J.H. 2008. Practical succession planning for the family-owned business, Journal of Practical Estate Planning, Feb: 27-60. HUME, S.A. 1999. An assessment of risk of family business failure, unpublished doctoral thesis, Antioch University, New Hampshire.

IBRAHIM, A.B. \& ELLIS, W.H. 2004. Family business management: concepts and practice $\left(2^{\text {nd }} \mathrm{ed}\right.$.) Dubuque, IA: Kendall/Hunt.

JAFFE, D.T. 1991. Working with the ones you love: Strategies for a successful family business, Berkeley, CA: Conari Press.

KLEIN, S.B., ASTRACHAN, J.H. \& SMYRNIOS, K.X. 2005. The F-PEC scale of family influence: construction, validation, and further implication for theory, Entrepreneurship Theory and Practice, 29(3): 321-339.

LANSBERG, I. 1999. Succeeding generations: Realizing the dream of families in business, Boston, MA: Harvard Business School Press.

LEA, J.W. 1991. Keeping it in the family: successful succession of the family business, New York, NY: Wiley. MATTHEWS, C.H., MOORE, T.W. \& FIALKO, A.S. 1999. Succession in the family firm: a cognitive categorization perspective, Family Business Review, 12(2): 159-169.

MEGGINSON, W.L., SMART, S.B. \& GRAHAM, J.R. 2010. Financial management ( $3^{\text {rd }}$ ed.) Singapore: South-Western.

MORCK, R. \& YEUNG, B. 2004. Family control and the rent seeking society, Entrepreneurship theory and practice, 28(4): 391-409.

NATIONAL SMALL BUSINESS ACT see South Africa.

NATIONAL SMALL BUSINESS AMENDMENT

ACT see South Africa.

NEUBAUER, F. \& LANK, A.G. 1998. The family business: its governance for sustainability, Hampshire: MacMillan.

NUNNALLY, J. \& BERNSTEIN, I.H. 1994.

Psychometric theory ( $3^{\text {rd }}$ ed.) New York, NY: McGrawHill.

PAGE, C. \& MEYER, D. 2000. Applied research design for business and management, Roseville: McGraw-Hill. POTTS, T.L., SCHOEN, J.E., LOEB, M.E., \& HULME, F.S. 2001. Effective retirement for family business owner-managers: perspective of financial planner, Part 2, Journal of Financial planning, July. RAWLS, L.H. 1999. Seeking succession: how to continue the family business legacy, Maitland, FL: Horizon Business Press.

RIVERS, D.W. 2005. Prescriptions for a healthy family business, Raleigh, NC: The Family Firm Institute. ROBBERTS, J. 2006. Evaluation of the unique challenges facing family businesses in South Africa, unpublished MBA dissertation, North-West University, Potchefstroom, South Africa.

RYAN, C. 1995 . Are family businesses better?, Productivity South Africa, March/April: 11-13.

SAS INSTITUTE 2005. SAS Institute Inc., $S A S$ OnlineDoc ${ }^{\circledR}$, Version 9.1, Cary, NC: SAS Institute. SHANOFF, B. 2006. Avoiding family feuds, Waste Age, Feb.

SHARMA, P. 1997. Determinants of the satisfaction of the primary stakeholders with the succession process in family firms, unpublished doctoral thesis, University of Calgary, Calgary, Canada.

SHARMA, P., CHUA, J.H. \& CHRISMAN, J.J. 2000.

Perceptions about the extent of succession planning in Canadian family businesses, Canadian Journal of Administrative Sciences, 17(3): 233-244.

SHORT, D.G., LIBBY, R., LIBBY, P.A. 2007. Financial accounting: a global perspective ( $5^{\text {th }} \mathrm{ed}$.) New York, NY: McGraw-Hill Irwin.

SONFIELD, M.C. \& LUSSIER, R.N. 2004.

First-second and third-generation family firms: a comparison, Family Business Review, 17(3): 189-202. SOUTH AFRICA 1996. National Small Business Act (Act 102 of 1996) Government Gazette, 377(17612). SOUTH AFRICA 2004) National Small Business Amendment Act (Act 29 of 2004), Government Gazette, 474(27101).

SPSS INC. 2008 SPSS $® 16.0$ for Windows, Release 16.0, Copyright $₫$ by SPSS Inc., Chicago, Ill.: SPSS.

STEIER, L.P. \& WARD, J.L. 2006. If theories of family enterprise really do matter, so does change in management education, Entrepreneurship Theory and Practice, 30(6): 887-895.

STURGILL, T.C. 1998. The states, too, demand their pound of flesh, Family Business, 9(3): 60-63.

SWART, H.C. 2005a. Evaluation of the factors that ensure long-term sustainability of family businesses, unpublished MBA dissertation, North-West University, Potchefstroom, South Africa.

SWART, P.J. 2005b. Unique challenges facing family businesses, unpublished MBA dissertation, North-West University, Potchefstroom, South Africa.

THOMPSON, B. 2001. Significance, effect sizes, stepwise methods, and other issues: strong arguments move the field, Journal of Experimental Education, 70: 80-93.

VAN DER MERWE, S.P. 1998. Formal planning in family businesses in the Vaal Triangle, unpublished doctoral thesis, North-West University, Potchefstroom, South Africa.

VAN DER MERWE, S.P. \& ELLIS, S.M. 2007. An exploratory study of some of the determinants of harmonious family relationships in small and medium- 
sized family businesses, Management Dynamics, 16(4): 24-35.

VENTER, E. 2003a. The succession process in small and medium-sized family businesses in South Africa, unpublished doctoral thesis, University of Port Elizabeth, Port Elizabeth, South Africa.

VENTER, E. \& BOSHOFF, C. 2007. The influence of organisation-related factors on the succession process in small and medium-sized family businesses, Management Dynamics, 16(1): 42-55.

VENTER, E., BOSHOFF, C. \& MAAS, G. 2003. The influence of relational factors on successful succession in family business: a comparative study of owner- managers and successors, South African Journal of Business Management, 34(4): 1-13.

VENTER, W.P. 2003b. The role of familiness in the performance of family business groups, M. Phil dissertation, Rand Afrikaans University, Johannesburg, South Africa.

VILLALONGA, B. \& AMIT, R. 2006. How do family ownership, control and management affect firm value?, Journal of Financial Economics, 80: 385-417.

VOELLER, M., FAIRBURN, L. \& THOMPSON, W. 2002. Exit right: A guided tour of succession planning for families-in-business-together ( $2^{\text {nd }}$ ed.) Toronto: Summit Run. 


\section{Appendix 1}

\section{Items measuring the latent variables}

\begin{tabular}{|c|c|}
\hline Item & Statement \\
\hline \multicolumn{2}{|r|}{ ESTATE PLANNING (EP) } \\
\hline EP1 & $\begin{array}{l}\text { Written decisions exist about the distribution of the family assets and ownership to the younger } \\
\text { generation after retirement of the senior generation family members }\end{array}$ \\
\hline EP2 & The goals of the estate plan are known to the family \\
\hline EP3 & The estate plan addresses future claims against the estate (e.g. previous marriages, minor children) \\
\hline EP4 & $\begin{array}{l}\text { The senior generation family members have signed wills that were reviewed and updated during } \\
\text { the past two years }\end{array}$ \\
\hline EP5 & The estate plan addresses the implications of the current and the heir's future form of enterprise \\
\hline EP6 & $\begin{array}{l}\text { The senior generation family members have written estate plans that meet the unique needs of the } \\
\text { family business }\end{array}$ \\
\hline EP7 & The estate plan provides in case of disability of the senior generation family members \\
\hline EP8 & $\begin{array}{l}\text { Provision was made in the estate plan for threats such as divorce, matrimonial property system } \\
\text { and insolvency }\end{array}$ \\
\hline EP9 & The estate plan meets the requirements to minimise estate tax. \\
\hline \multicolumn{2}{|r|}{ RETIREMENT PLANNING (Ret) } \\
\hline Ret1 & $\begin{array}{l}\text { Sufficient retirement packages are available to the senior generation family members in the family } \\
\text { business }\end{array}$ \\
\hline Ret2 & $\begin{array}{l}\text { The senior generation family members have determined their expected current and future lifestyle } \\
\text { expenditures }\end{array}$ \\
\hline Ret3 & $\begin{array}{l}\text { Sufficient provision was made so that the senior generation family members will be financially } \\
\text { secure after retirement }\end{array}$ \\
\hline Ret4 & $\begin{array}{l}\text { The senior generation family members will not be financially dependent on the family business } \\
\text { after retirement }\end{array}$ \\
\hline Ret5 & The retirement programme of the family business is adequately funded \\
\hline Ret6 & $\begin{array}{l}\text { The family business has a financial system in place that ensures the financial independence of its } \\
\text { retirees }\end{array}$ \\
\hline Ret7 & $\begin{array}{l}\text { The existing capital available to the senior generation family members will generate the income } \\
\text { and cashflow to meet their expenditure requirements for the remainder of their lifetimes }\end{array}$ \\
\hline \multicolumn{2}{|r|}{ PERCEIVED LIQUIDITY OF THE BUSINESS AFTER TRANSFER (Liq) } \\
\hline Liq1 & $\begin{array}{l}\text { The family business will be financially secure after the retirement of the senior generation family } \\
\text { members }\end{array}$ \\
\hline Liq2 & $\begin{array}{l}\text { Sufficient capital will be available to successfully manage the family business after the retirement } \\
\text { of the senior generation family members }\end{array}$ \\
\hline Liq3 & $\begin{array}{l}\text { The financial retirement needs of the senior generation family members should not put the family } \\
\text { business under financial strain }\end{array}$ \\
\hline Liq4 & The liquidity of the estate when senior generation family members pass away was determined \\
\hline
\end{tabular}




\begin{tabular}{|c|c|}
\hline \multicolumn{2}{|r|}{ READINESS OF THE OWNER-MANAGER TO LET GO (Read) } \\
\hline Read1 & $\begin{array}{l}\text { The senior generation executive manager feels increasingly that his/her direct involvement in the } \\
\text { family business is not essential for its survival }\end{array}$ \\
\hline Read2 & $\begin{array}{l}\text { The senior generation executive manager is willing to delegate authority to younger family } \\
\text { members }\end{array}$ \\
\hline Read3 & The senior generation executive manager will be financially secure after his/her retirement \\
\hline Read4 & $\begin{array}{l}\text { The senior generation executive manager talks with other businessmen who are also in the } \\
\text { process of transferring management of their family business to the younger family members }\end{array}$ \\
\hline Read5 & The senior generation executive manager will be willing to relinquish control of the family business \\
\hline Read6 & $\begin{array}{l}\text { The senior generation executive manager has passionate interests outside the family business to } \\
\text { fill his/her time after retirement (hobbies, sport, and other interests) }\end{array}$ \\
\hline Read7 & $\begin{array}{l}\text { The senior generation executive manager is involved in activities outside the context of the family } \\
\text { business }\end{array}$ \\
\hline Read8 & $\begin{array}{l}\text { The senior generation executive manager feels that the younger family members are capable of } \\
\text { managing the family business after his/her retirement }\end{array}$ \\
\hline \multicolumn{2}{|r|}{ SUITABILITY OF THE SUCCESSOR (Suit) } \\
\hline Suit1 & $\begin{array}{l}\text { The prospective successor(s) possess(es) the necessary skills to ensure the success of the family } \\
\text { business after succession }\end{array}$ \\
\hline Suit2 & $\begin{array}{l}\text { The prospective successor(s) has/have the necessary leadership skills to manage the family } \\
\text { business after the transfer of management. }\end{array}$ \\
\hline Suit3 & $\begin{array}{l}\text { The prospective successor(s) believe(s) in his/her ability to successfully manage the family } \\
\text { business. }\end{array}$ \\
\hline Suit4 & $\begin{array}{l}\text { The prospective successor(s) possess(es) the knowledge and experience needed to ensure the } \\
\text { success of the family business after succession }\end{array}$ \\
\hline Suit5 & $\begin{array}{l}\text { There is a good fit between the skills and knowledge of the prospective successor(s) and what is } \\
\text { needed for the family business to succeed }\end{array}$ \\
\hline \multicolumn{2}{|r|}{ EXPECTED OUTCOME OF THE SUCCESSION (Out) } \\
\hline Out1 & It is expected that the family business will perform equally well after succession \\
\hline Out2 & $\begin{array}{l}\text { It is expected that it will be possible to maintain the existing contracts and client base after } \\
\text { succession }\end{array}$ \\
\hline Out3 & $\begin{array}{l}\text { It is expected that all family members will support the successor(s) once the leadership has been } \\
\text { transferred to him/her }\end{array}$ \\
\hline Out4 & It is expected that family relationships will remain good after succession \\
\hline Out5 & $\begin{array}{l}\text { It is expected that the employees of the family business will support the successor(s) once the } \\
\text { leadership has been transferred to him/her }\end{array}$ \\
\hline
\end{tabular}

